\title{
Upregulation of TNF- $\alpha$ by Triglycerides is Mediated by MEK1 Activation in Jurkat T Cells
}

\author{
Jaewon Lim ${ }^{\S, *}$, Eun Ju Yang ${ }^{\S, *}$ and Jeong Hyun Chang ${ }^{\dagger ; *}$ \\ Department of Clinical Laboratory Science, College of Medical Sciences, \\ Daegu Haany University, Gyeongsan 38610, Korea
}

\begin{abstract}
Triglyceride (TG) is known to be associated with inflammatory disease including atherosclerosis. In a variety of atherosclerosis models, $\mathrm{T}$ lymphocytes are localized in the earliest lesions of atherosclerosis. T cell associated cytokines such as TNF- $\alpha$ and IFN- $\gamma$ have pre-dominant inflammatory effects in chronic vascular diseases. In our previous study, we found that the expression of TNF- $\alpha$ and its receptor, TNF- $\alpha$ R was increased when Jurkat T lymphocyte cell lines were exposed to TGs. Therefore, experiments were conducted to determine which cell signaling pathway are involved in the increase of TNF- $\alpha$ and TNF- $\alpha$ R expression by TGs. To identify signal transduction pathways involved in TG-induced upregulation of TNF- $\alpha$, we treated TG-exposed Jurkat T cells with specific inhibitors for MEK1, PI3K, NF- $\kappa$ B and PKC. We found that inhibition of the MEK1 pathway blocked TG-induced upregulation of TNF- $\alpha$. However, the expression level of TNF- $\alpha \mathrm{R}$ did not change with any signal transduction inhibitor. Based on this observation, we suggest that increase of exogenous TG induces increase of TNF- $\alpha$ expression through MEK1 pathway in Jurkat T cells. In addition, it was confirmed that the increase of TNF- $\alpha$ and TNF- $\alpha$ R expression by TGs occurs via different pathways.
\end{abstract}

Key Words: Triglyceride (TG), TNF- $\alpha$, TNF- $\alpha$ R, MEK1, Jurkat T cells

\section{INTRODUCTION}

Tumor necrosis factor- $\alpha(\mathrm{TNF}-\alpha)$ is one of the typical inflammatory cytokines secreted by inflammatory cells including $\mathrm{T}$ cells. It not only stimulates inflammation reaction around the site of inflammation lesion, but also accumulates immune cells that are involved in other inflammatory responses, such as macrophages in the inflammation lesions (Burger and Dayer, 2002; Firestein and Zvaifler, 2002). TNF- $\alpha$ is known as a cytokine that bind to TNF- $\alpha$ receptor
(TNF- $\alpha \mathrm{R})$ present in most nucleated cells. When TNF- $\alpha$ binds to the TNF- $\alpha \mathrm{R}$, it transmits a signal to the inside of the cell and causes various reactions such as inflammation or apoptosis. The intracellular signaling pathway to receptor binding is a very complex phenomenon, accompanied by phosphorylation or ubiquitination of each target signaling substances (Juge-Aubry et al., 2005; Lira et al., 2009). In the inflammatory response, the signaling molecule that plays a key role in the intracellular signaling caused by the interaction between TNF- $\alpha$ and TNF- $\alpha \mathrm{R}$ is nuclear factor $\kappa \mathrm{B}$ $(\mathrm{NF}-\kappa \mathrm{B})$. When stimulation signal by TNF- $\alpha$ is delivered

Received: August 17, 2018 / Revised: September 12, 2018 / Accepted: September 13, 2018

*Professor.

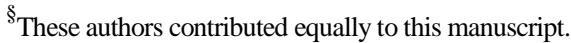

†Corresponding author: Jeong Hyun Chang. Department of Clinical Laboratory Science, College of Medical Science, Daegu Haany University, Gyeongsan 38610, Korea.

Tel: +82-53-819-1350, Fax: +82-53-819-1353, e-mail: jhchang@dhu.ac.kr

(C) The Korean Society for Biomedical Laboratory Sciences. All rights reserved.

(c) This is an Open Access article distributed under the terms of the Creative Commons Attribution Non-Commercial License (http://creativecommons.org/licenses/by-nc/3.0/) which permits unrestricted non-commercial use, distribution, and reproduction in any medium, provided the original work is properly cited. 
into the cell, inhibitor of $\kappa \mathrm{B} \alpha(\mathrm{I} \kappa \mathrm{B} \alpha)$ is phosphorylated by phosphorylated inhibitor of $\kappa \mathrm{B}$ kinase (IKK). I $\kappa \mathrm{B} \alpha$ usually binds to NF- $\kappa B$ and inhibits the activation of NF- $\kappa$ B signaling pathway. The phosphorylated $\mathrm{I} \kappa \mathrm{B} \alpha$ is released from $\mathrm{NK}-\kappa \mathrm{B}$ in the cytoplasm, and NF- $\kappa \mathrm{B}$ migrates from the cytoplasm to the nucleus. Thereafter, NF- $\mathrm{BB}$ acts as a transcription factor, producing a variety of inflammatory cytokines and accelerating the inflammatory response (Costa Rosa, 2004; Kanayama et al., 2004; Mund et al., 2007).

In vascular endothelial inflammatory diseases including atherosclerosis, a chronic inflammatory arterial disease, various cytokine are known to be involved, one of which is TNF- $\alpha$. Studies have shown that the expression levels of TNF- $\alpha$ are increased in a variety of immune cells found in early lesions of atherosclerosis. And that increased expression of TNF- $\alpha$ directly and indirectly exacerbates inflammatory lesions (Libby et al., 2002; Robertson and Hansson, 2006). Therefore, increased expression of TNF- $\alpha$ in immune cells involved in chronic inflammatory vascular disease is a very important pathogenic factor.

Among the various factors that cause damage to the blood vessels by the chronic inflammatory response, triglycerides (TGs) have been regarded as one of the causing factor (Gotto, 1998; Aronis et al., 2009). Several studies have reported that elevated concentrations of TGs in the blood cause inflammatory damage to vascular endothelial cells and promotes the development of vascular inflammatory diseases such as atherosclerosis (Sofer et al., 1992; Kastelein et al., 2008). The Framingham Heart Study (FHS), a large observational study of coronary artery disease (CAD), demonstrates that patients with hyperlipidemia with triglyceride (TG) levels above $250 \mathrm{mg} / \mathrm{dL}$ had a two-fold increased risk of CAD (Castelli, 1992; Malloy and Kane, 2001). However, a detailed mechanism of how TGs affect inflammatory lesions of the blood vessels is still being studied, and there are still some unknowns.

In pathological conditions of atherosclerosis, immune cells such as T lymphocytes and macrophages are involved in the increase of inflammation caused by hyperlipidemia, and these cells are observed in the inflammatory lesions (Libby et al., 2002). T lymphocytes secrete a variety of cytokines, of which TNF- $\alpha$ and interferon- $\gamma$ (IFN- $\gamma$ ) are known to in- crease inflammatory effects in the human immune system. These cytokines stimulates other immune cells, such as macrophages and monocytes, to increase the secretion of inflammatory cytokines, thus accelerating the inflammatory response (Burger and Dayer, 2002). Therefore, the secretion of inflammatory cytokines from $\mathrm{T}$ lymphocytes during the development of inflammatory lesions in the blood vessels is an important mediator.

In this study, we conducted an experiment to determine the relationship between TNF- $\alpha$ expression and triglyceride, which are closely related to the inflammatory response. Then, it was confirmed that the expression of TNF- $\alpha$ by TG was increased in Jurkat $\mathrm{T}$ cells, a cell line model of $\mathrm{T}$ lymphocytes. Furthermore, the expression level of TNF- $\alpha$ receptor, which is closely related to intracellular signal transduction of TNF- $\alpha$, is also increased by TG in Jurkat T cells. Upregulation of TNF- $\alpha$ occurred through activation of the MEK1 pathways. Our results suggest that the increase of TG in the blood is thought to contribute to an increase in the expression of TNF- $\alpha$ and TNF- $\alpha \mathrm{R}$ in T lymphocytes, thereby further exacerbating inflammatory lesions in the vessel.

\section{MATERIALS AND METHODS}

\section{Materials}

TG emulsion (Lipofundin ${ }^{\circledR}$ MCT/LCT 20\%) was purchased from B. Braun Melsungen AG (Melsungen, Germany). Lipofundin ${ }^{\circledR}$ MCT/LCT $20 \%$ was used to deliver TG into cells in previous studies. The composition of Lipofundin ${ }^{\circledR}$ MCT/LCT 20\% was as follows: $100 \mathrm{~g} / \mathrm{L}$ medium chain triglyceride, soybean oil, glycerol, egg lecithin, all-rac- $\alpha$ tocopherol, sodium oleate and water. Hereafter, Lipofundin ${ }^{\circledR}$ MCT/LCT $20 \%$ will be referred to as TG for convenience (Aronis et al., 2005). TRIzol ${ }^{\circledR}$ for RNA isolation was obtained from Invitrogen (Carlsbad, CA, USA). Chemical inhibitors for classical PKC (RO31-7549, $5 \mu \mathrm{M}$ ), MEK1 (PD98059, $10 \mu \mathrm{M})$ and PI3K (LY294002, $20 \mu \mathrm{M}$ ) were purchased from Calbiochem (Darmstadt, Germany). Specific inhibitor of NF- $\mathrm{B}$ (BAY11-7085, $2 \mu \mathrm{M}$ ) was purchased from Enzo Life Sciences (New York, NY, USA). Dimethyl sulfoxide (DMSO) was obtained from Sigma-Aldrich (St. Louis, MO, USA). All inhibitors were dissolved as stock solutions in 
DMSO and stored at $-20^{\circ} \mathrm{C}$ prior to usage.

\section{Cell culture}

The Jurkat acute T lymphocyte leukemia cell line (ATCC, Manassas, VA, USA) was grown in RPMI 1640 media supplemented with $10 \%$ fetal bovine serum (FBS), 1\% MEM non-essential amino acid solution, $1 \mathrm{mM}$ HEPES, $100 \mu \mathrm{M}$ sodium pyruvate and $1 \%$ penicillin-streptomycin and maintained at $37^{\circ} \mathrm{C}$ in a humidified atmosphere with $5 \% \mathrm{CO}_{2}$. Jurkat cells were seeded in 6-well plates at a density of 2.5 $\times 10^{5}$ cells/well for $24 \mathrm{~h}$. Thereafter, Jurkat cells were incubated with TG and/or chemical inhibitors for $48 \mathrm{~h}$.

\section{RNA extraction and semi-quantitative reverse transcrip- tase PCR (RT-PCR)}

Total RNA was isolated from Jurkat T lymphocytes using Trizol $^{\circledR}$ reagent according to the manufacturer's instructions. cDNA was synthesized by reverse transcription with $2 \mu \mathrm{g}$ total RNA, $0.25 \mu \mathrm{g}$ of random hexamer (Invitrogen) and 200 unit of Moloney murine leukemia virus reverse transcriptase (MMLV-RT; Invitrogen) for $10 \mathrm{~min}$ at $25^{\circ} \mathrm{C}, 50 \mathrm{~min}$ at $37^{\circ} \mathrm{C}$ and $15 \mathrm{~min}$ at $70^{\circ} \mathrm{C}$. cDNA was PCR amplified using Prime Taq premix PCR kit (Genet Bio, Chungnam, Korea) for 25 50 cycles using specific primers. Primer sequences are as follows: TNF- $\alpha$; 5'-AGC CCA TGT TGT AGC AAA CC-3' (forward), 5'-CTG AGT CGG TCA CCC TTC TC-3' (reverse), IFN- $\gamma$; 5'-ACC GAA TAA TTA GTC AGC TT-3' (forward), 5'-AGT TAT ATC TTG GCT TTT CA-3' (reverse), TGF- $\beta$; 5'-GGG CTACCA TGC CAA CTT CT-3' (forward), 5'-GAC ACA GAG ATC CGC AGT CC-3' (reverse), TNF$\alpha R ;$ 5'-CTC TCC CCT CCT CTC TGC TT-3' (forward), 5'ATT CCC ACC AAC AGC TCC AG-3' (reverse). GAPDH was used as an internal control (Son et al., 2013). PCR products were electrophoresed on $2 \%(\mathrm{w} / \mathrm{v})$ agarose gels containing $0.5 \mu \mathrm{g} / \mathrm{mL}$ ethidium bromide and the product size determined by comparison to $100 \mathrm{bp}$ DNA ladder marker (Intron, Gyeonggi, Korea). Gel images were taken using Gel $\mathrm{Doc}^{\mathrm{TM}} \mathrm{XR}+$ system (Bio-Rad, Hercules, CA, USA). The PCR product band intensity was measured and normalized against GAPDH using Image $\mathrm{Lab}^{\mathrm{TM}}$ software (version 4.1, Bio-Rad).

\section{Statistical analysis}

$P$-values were calculated using either the Student's $t$-test. Values are shown as mean and standard error of the mean (SEM). Each experiment was conducted three times and the data pooled for analysis.

\section{RESULTS}

The triglyceride increases TNF- $\alpha$ expression in Jurkat T lymphocytes

T lymphocytes secrete inflammatory cytokines such as TNF- $\alpha$ and IFN- $\gamma$ in vascular inflammatory lesions and are

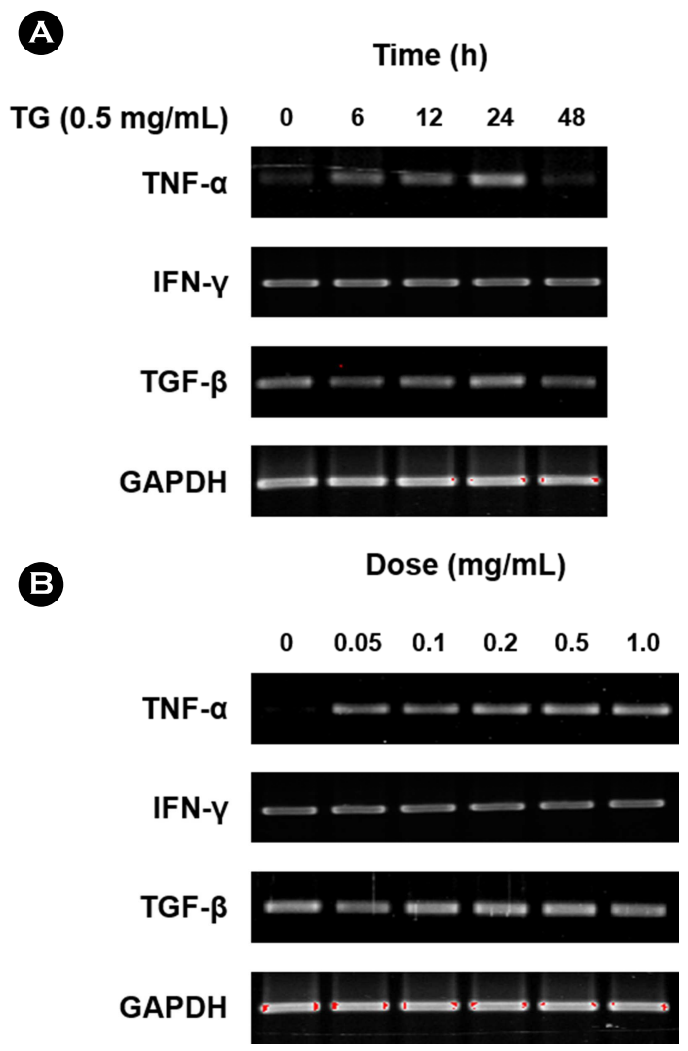

Fig. 1. TG affects the mRNA expression of inflammationassociated cytokines in the Jurkat T lymphocytes. (A) Jurkat $\mathrm{T}$ lymphocytes were incubated with TG $(0.5 \mathrm{mg} / \mathrm{mL})$ for indicates times $(0,6,12,24$, and 48 h). (B) Jurkat T lymphocytes were incubated with indicates concentration of TG $(0,0.05,0.1,0.2,0.5$, and $1.0 \mathrm{mg} / \mathrm{mL}$ ) for $24 \mathrm{~h}$. cDNA was prepared from extracted total RNA and subjected to PCR to amplify inflammation-associated cytokines (TNF- $\alpha$, IFN- $\gamma$, and TGF- $\beta$ ). The PCR products were analyzed on a $2 \%$ agarose gel. GAPDH was used as internal control. Data were collected from three independent experiments. 

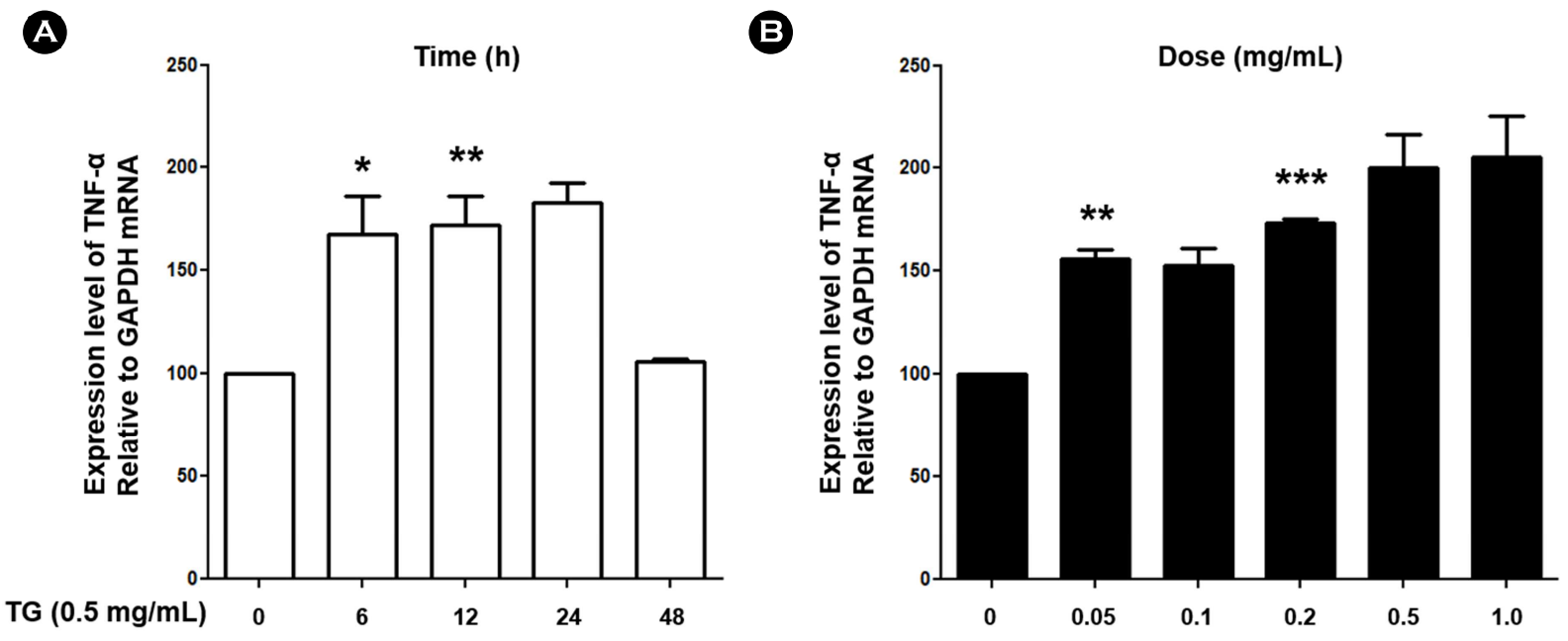

Fig. 2. TG increased expression level of TNF- $\alpha$ in Jurkat $T$ lymphocytes. (A) Jurkat T lymphocytes were treated with $\mathrm{TG}(0.5 \mathrm{mg} / \mathrm{mL})$ for indicated times $(0,6,12,24$, and $48 \mathrm{~h})$. (B) Jurkat T lymphocytes were treated with indicated concentration of TG $(0,0.05,0.1,0.2$, 0.5 , and $1.0 \mathrm{mg} / \mathrm{mL}$ ) for $24 \mathrm{~h}$. cDNA was prepared from extracted total RNA and subjected to PCR to amplify TNF- $\alpha$. Densitometric analysis was performed. Data are expressed as the mean \pm SD and are presented as the expression levels of TNF- $\alpha$ mRNA relative to GAPDH mRNA (The mRNA expression level of TNF- $\alpha$ relative to GAPDH in Jurkat T lymphocytes treated with $0.5 \mathrm{mg} / \mathrm{mL}$ TG for $0 \mathrm{~h}$ was set as 100). Data are from three independent experiments. GAPDH was used as an internal control. Values are shown as mean and standard error. $P$-values were determined by Student's $t$-test $(* P<0.05$, $* * P<0.01$, and $* * * P<0.001)$.

known to contribute to the development of early lesions (Libby, 2012). Therefore, in order to examine whether TGs affect inflammatory responses by $\mathrm{T}$ lymphocytes, experiments were conducted to confirm the mRNA expression level of TNF- $\alpha$, INF- $\gamma$ and TGF- $\beta$. Jurkat T lymphocytes were treated with TG in time- and dose-dependent manner and expression of TNF- $\alpha$, INF- $\gamma$ and TGF- $\beta$ assessed by RT-PCR. We found that expression of TNF- $\alpha$ was increased by TG treatment in Jurkat $\mathrm{T}$ cells whereas expression of IFN- $\gamma$ and TGF- $\beta$ remained unchanged (Fig. 1). As a result of confirming the increase of TNF- $\alpha$ expression by TG, it was confirmed that the expression level of TNF- $\alpha$ increased with increasing treatment concentration of TG. In addition, expression level of TNF- $\alpha$ was highest at $24 \mathrm{~h}$ after treatment with TG, and then decreased after that (Fig. 2). These results indicate that TG treatment up-regulated mRNA expression of TNF- $\alpha$ in Jurkat T cell suggesting that TG can potentially enhance inflammation response in lesions.

\section{TG up-regulates TNF- $\alpha$ R expression in Jurkat T lym- phocytes in a time- and dose-dependent manner}

In local and systemic inflammatory diseases involving atherosclerosis, an increase of TNF- $\alpha$ acts in the direction of worsening the disease. The expression level of TNF- $\alpha \mathrm{R}$, a receptor for TNF- $\alpha$, is also involved in the development of inflammatory diseases (Gil et al., 2007; Lira et al., 2009). Therefore, we confirmed whether triglycerides also affect the expression of TNF- $\alpha \mathrm{R}$ in $\mathrm{T}$ lymphocytes. Jurkat $\mathrm{T}$ cells were treated with $\mathrm{TG}(0.5 \mathrm{mg} / \mathrm{mL})$ for the indicated times $(0,6,12,24$ and $48 \mathrm{~h})$ and TNF- $\alpha \mathrm{R}$ expression assessed by RT-PCR analysis. We found that TNF- $\alpha$ R expression began to increase by $6 \mathrm{~h}$ after TG treatment and continued to increase for $24 \mathrm{~h}$ (Fig. 3A and 3B). We next determined the concentration at which TG could up-regulate TNF- $\alpha$ R expression. Jurkat $\mathrm{T}$ cells were treated with $\mathrm{TG}(0,0.05,0.1,0.2$, $0.5,1.0 \mathrm{mg} / \mathrm{mL}$ ) for $48 \mathrm{~h}$ and TNF- $\alpha \mathrm{R}$ expression assessed by RT-PCR. We found that $0.2 \mathrm{mg} / \mathrm{mL}$ of TG was sufficient to induce TNF- $\alpha \mathrm{R}$ expression by $48 \mathrm{~h}$ (Fig. 3A and 3C). These results indicate that gene expression of TNF- $\alpha \mathrm{R}$ in Jurkat $\mathrm{T}$ cells is up-regulated in a time- and dose-dependent manner by TG treatment. 

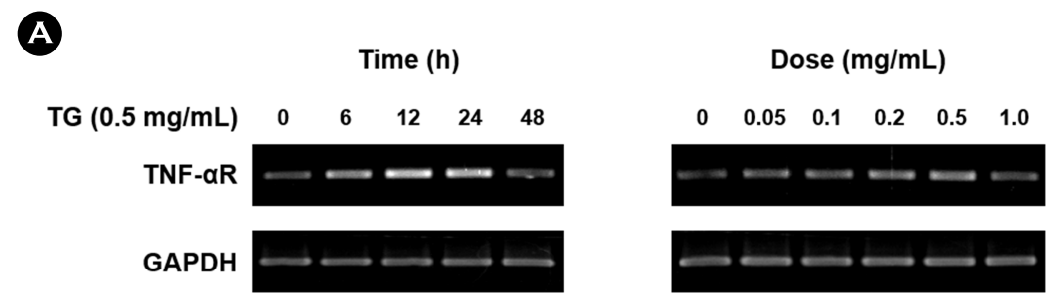

B

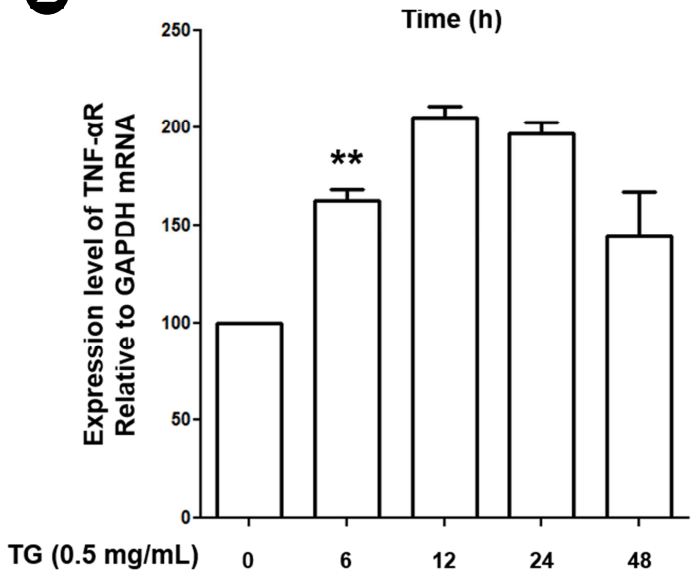

C

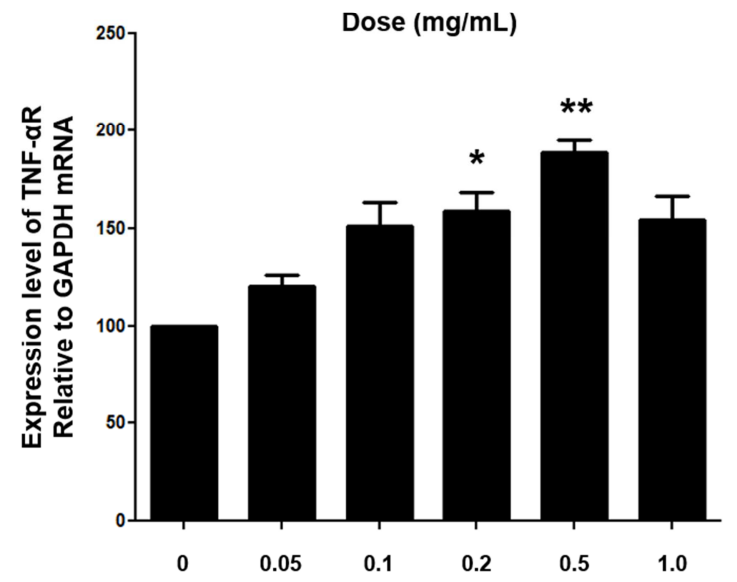

Fig. 3. TG increased expression level of TNF- $\alpha$ R in Jurkat $T$ lymphocytes. (A) Jurkat T lymphocytes were treated with indicates concentration of TG $(0,0.05,0.1,0.2,0.5$, and $1.0 \mathrm{mg} / \mathrm{mL})$ for indicates times $(0,6,12,24,48 \mathrm{~h})$. cDNA was prepared from extracted total RNA and subjected to PCR to amplify TNF- $\alpha$ R. The PCR products were analyzed on a $2 \%$ agarose gel. GAPDH was used as internal control. Data were collected from three independent experiments. (B) and (C) Densitometric analysis was performed. Data are expressed as the mean \pm SD and are presented as the expression levels of TNF- $\alpha$ R mRNA relative to GAPDH mRNA (The mRNA expression level of TNF- $\alpha$ R relative to GAPDH in Jurkat T lymphocytes treated with $0.5 \mathrm{mg} / \mathrm{mL}$ TG for $0 \mathrm{~h}$ was set as 100). Data are from three independent experiments. GAPDH was used as an internal control. Values are shown as mean and standard error. $P$-values were determined by Student's $t$-test $(* P<0.05$, and $* * P<0.01)$.

\section{Modulation of TNF- $\alpha$ expression in TG treated Jurkat $T$ cells is mediated by MEK1 pathways}

To identify cell signaling pathways involved in upregulation of TNF- $\alpha$ and TNF- $\alpha \mathrm{R}$ in TG treated Jurkat T cells, TG treated Jurkat T cells were co-treated with chemical inhibitors of select cell signaling pathways and TNF- $\alpha$ and TNF- $\alpha \mathrm{R}$ expression assessed by RT-PCR analysis. The following inhibitors were tested: NF- $\mathrm{BB}$ (BAY11-7085), MEK1 (PD98059), PKC (RO31-7549) and PI3-K (LY294002). We found that the MEK1 (PD98059) dramatically blocked TNF$\alpha$ up-regulation by TG (Fig. 4A and 4B). In contrast, It was confirmed that the increase of TNF- $\alpha$ R expression was maintained in any inhibitor treatment (Fig. 4A and 4C). These results suggest that TG-induced up-regulation of TNF- $\alpha$ expression requires activation of the MEK1. Furthermore, these results indicate that increased expression of TNF- $\alpha$ and $\mathrm{TNF}-\alpha \mathrm{R}$ is regulated by different signaling pathways.

\section{DISCUSSION}

Studies on the correlation between hypertriglyceridemia and inflammatory lesions such as atherosclerosis are continuing, and TGs are known to be an independent factor that exacerbates the inflammation of intravascular lesions. Furthermore, a variety of immune cells are involved in the development of these inflammatory lesion sites, and it is known that macrophages and $\mathrm{T}$ lymphocytes are involved directly or indirectly. In the early development of the inflammatory response, the inflammatory mediators secreted by these cells activate several other immune cells, including themselves, and this process further exacerbates the inflam- 

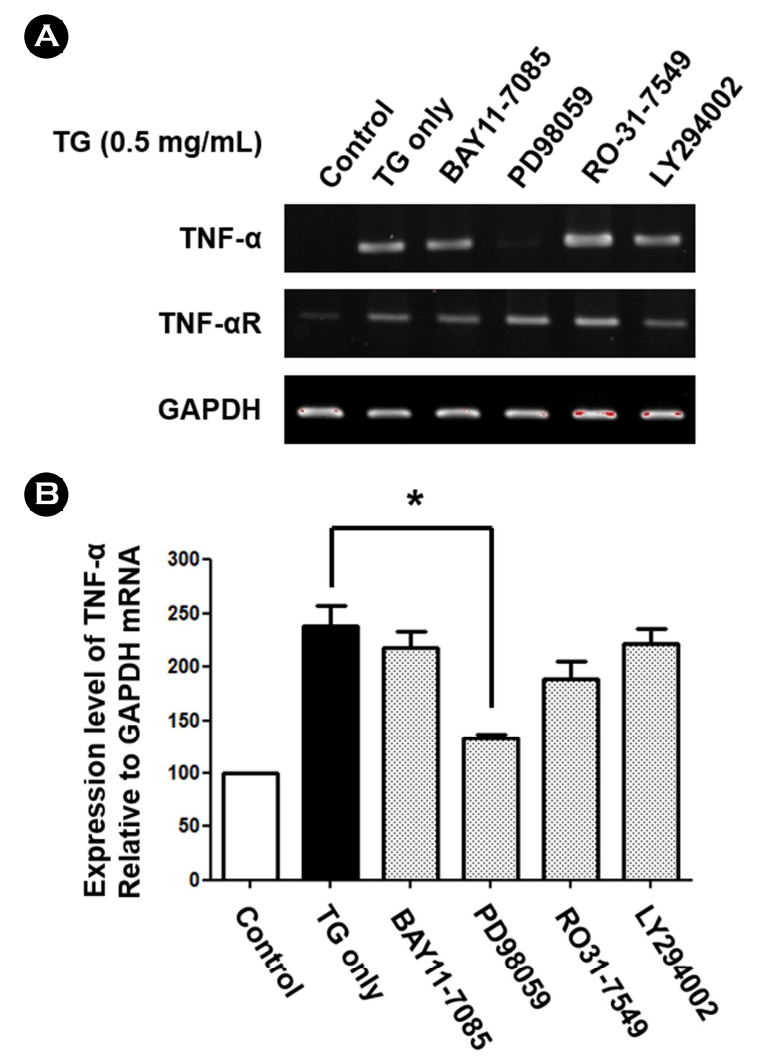

C

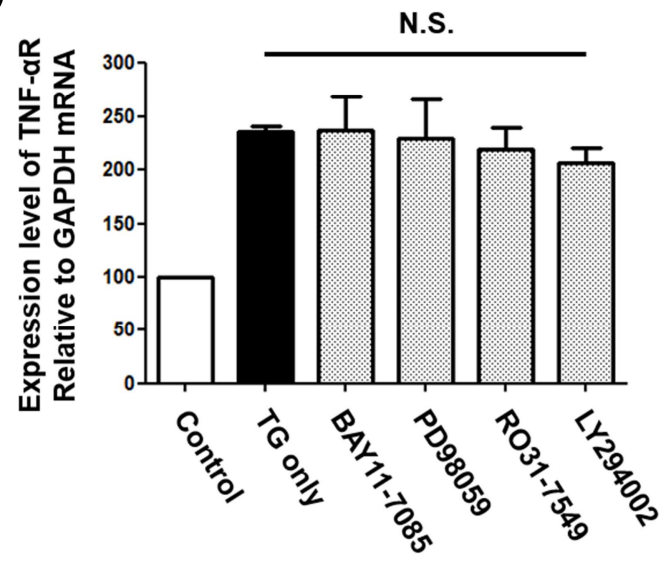

Fig. 4. TG up-regulates the mRNA expression of TNF- $\alpha$ which is mediated by the MEK1 pathways. (A) Jurkat T lymphocytes were treated with specific inhibitors including $2 \mu \mathrm{M}$ of BAY 117085 (NF-kB inhibitor), $10 \mu \mathrm{M}$ of PD98059 (MEK1 inhibitor), 5 $\mu \mathrm{M}$ of RO31-7549 (PKC inhibitor) and $20 \mu \mathrm{M}$ of LY294002 (PI3K inhibitor) during TG treatment $(0.5 \mathrm{mg} / \mathrm{mL})$ for $48 \mathrm{~h}$ and RT-PCR analysis was performed. GAPDH was used as the internal control for calculating target genes' relative expressions. The PCR products were analyzed on $2 \%$ agarose gel and densitometry analysis was performed. (B) and (C) The mRNA expression level of TNF- $\alpha$ and TNF- $\alpha$ R relative to GAPDH in THP-1 macrophages treated without TG was set as a 100. Data are expressed as the mean \pm SD and are presented as the mRNA expression levels of TNF- $\alpha$ and TNF- $\alpha$ R relative to GAPDH mRNA. Data were collected from three independent experiments. Values are shown as mean and standard error. $P$-values were determined by the Student's $t$-test $(* P<0.05)$. matory lesions. TNF- $\alpha$ is one of the typical inflammatory mediators secreted by various immune cells including $\mathrm{T}$ lymphocytes. Increased expression of TNF- $\alpha$ activates immune cells such as macrophages, which are involved in the inflammatory reaction in inflammatory lesions, it contributes to worsening of the lesion sites.

Previous studies have shown that inflammatory lesions increase in both human and experimental animal models of vascular disease in the presence of hyperlipidemia, including increased TG. These studies also show that inflammatory cytokines such as TNF- $\alpha$ are currently increased in inflammatory lesions (Libby et al., 2002; Gil et al., 2007; Lira et al., 2009). According to Paiva et al., The expression of TNF- $\alpha$ and other inflammatory cytokines increases in mice when overexpressing Apolipoprotein CIII and inducing hypertriglyceridemia, leading to apoptosis of cells as well as increased inflammatory lesions (Paiva et al., 2017). Furthermore, inhibition of the action of TNF- $\alpha$ in the inflammatory response moderates the deterioration of these inflammatory lesions. Thus, the increased expression of TNF- $\alpha$ by TGs is a very important pathogenic factor in a variety of inflammatory diseases and regulating it is crucial in the developmental stage of the lesion (Ross, 1999; Costa Rosa, 2004; Libby, 2012). TNF- $\alpha \mathrm{R}$ is also closely related to the activation of inflammatory lesions. When the receptor binds to TNF- $\alpha$, the TNF receptor-associated factor (TRAF) protein is activated and consequently the $\mathrm{NF}-\kappa \mathrm{B}$ migrates to the nucleus, resulting in the expression of various inflammatory mediators such as IL-1 $\beta$ and TNF- $\alpha$ (Coppack, 2001; Lira et al., 2009). Thus, the increased expression of the TNF- $\alpha$ R promotes a variety of inflammatory immune cell responses, including $\mathrm{T}$ lymphocytes and macrophages, thereby contributing to the deterioration of inflammatory lesion sites. In this study, we conducted an experiment to investigate the correlation between TNF- $\alpha$ expression in T lymphocyte and TG. TG increased the expression of TNF- $\alpha$ in T Jurkat cells, also increased the expression of $\mathrm{TNF}-\alpha \mathrm{R}$, an intracellular signaling mediator of TNF- $\alpha$. Therefore, it is highly likely that Tlymphocyte is closely related to the increased expression of TNF- $\alpha$ and the development of inflammatory lesions associated with hypertriglyceridemia. We confirmed that TGs regulate the expression of TNF- $\alpha$ and TNF- $\alpha \mathrm{R}$ from trans- 
cription level. Therefore, we will further investigate whether the inflammatory response by TGs affects the secretion of cytokines such as TNF- $\alpha$ and the phosphorylation of inflammation associated signaling molecules.

In this study, experiments were conducted with specific chemical inhibitors to determine which cell signaling molecules are involved in the expression of TNF- $\alpha$ and TNF- $\alpha$ R. It was confirmed that the increase of TNF- $\alpha$ expression by triglyceride was inhibited by the MEK1 inhibitor. Several reports have shown that the expression of TNF- $\alpha$ is regulated by mitogen activated protein kinase (MAPK) group of signaling molecules (Boulton et al., 1991; Kyriakis et al., 1994). The MAPK signaling molecules are known to be involved in the inflammatory process. In general, MAPK pathways are divided into three groups: extracellular signal-regulated kinase (ERK) family, Jun N-terminal kinase (JNK)/stressactivated protein kinase family, and p38 family (Weinstein et al., 1992; Lee et al., 1994; Dziarski et al., 1996). According to Ajizian et al., treatment of RAW 264.7 cells with a MEK1 specific inhibitor (PD98059) decreases the expression of TNF- $\alpha$ by lipopolysaccharide (LPS). Furthermore, it is reported that the formation of iNOS protein and NO associated with the inflammatory response is also suppressed (Ajizian et al., 1999). As shown in this study, increased expression of TNF- $\alpha$ by TG is via MEK1. Thus, MEK1 is likely to be an important signaling molecule in the development of inflammatory lesions caused by TGs. Furthermore, the increased expression of TNF- $\alpha$ via MEK1 is also likely to be associated with activation of iNOS protein and NO production. Inhibition of MEK1 signaling can be used to identify candidates for reducing inflammatory responses caused by TGs. Apart from this result, the increase in the expression level of TNF- $\alpha$ R was not changed by other specific chemical inhibitors including MEK1. As we have seen, TNF- $\alpha \mathrm{R}$ is also an important pathogenic factor in inflammatory diseases, so we need to continue research to find out the mechanism of increased expression of TNF- $\alpha$ R. Although TNF- $\alpha$ and TNF$\alpha \mathrm{R}$ expression by TGs could not be elucidated, it is expected that the increase of TNF- $\alpha$ due to TG in Jurkat T lymphocytes via MEK1 will provide important information for the study of inflammatory lesions caused by hypertriglyceridemia.

\section{ACKNOWLEDGEMENTS}

This research was supported by National Research Foundation of Korea (NRF) grant funded by the Korea government Ministry of Science and ICT (No. 2017R1C1B5076998).

\section{CONFLICT OF INTEREST}

No conflict of interests exists for any of the authors.

\section{REFERENCES}

Ajizian SJ, English BK, Meals EA. Specific inhibitors of p38 and extracellular signal-regulated kinase mitogen-activated protein kinase pathways block inducible nitric oxide synthase and tumor necrosis factor accumulation in murine macrophages stimulated with lipopolysaccharide and interferon-gamma. J Infect Dis. 1999. 179: 939-944.

Aronis A, Aharoni-Simon M, Madar Z, Tirosh O. Triacylglycerolinduced impairment in mitochondrial biogenesis and function in j774.2 and mouse peritoneal macrophage foam cells. Arch Biochem Biophys. 2009. 492: 74-81.

Aronis A, Madar Z, Tirosh O. Mechanism underlying oxidative stress-mediated lipotoxicity: Exposure of j774.2 macrophages to triacylglycerols facilitates mitochondrial reactive oxygen species production and cellular necrosis. Free Radic Biol Med. 2005. 38: 1221-1230.

Boulton TG, Nye SH, Robbins DJ, Ip NY, Radziejewska E, Morgenbesser SD, DePinho RA, Panayotatos N, Cobb MH, Yancopoulos GD. Erks: A family of protein-serine/threonine kinases that are activated and tyrosine phosphorylated in response to insulin and ngf. Cell. 1991. 65: 663-675.

Burger D, Dayer JM. The role of human t-lymphocyte-monocyte contact in inflammation and tissue destruction. Arthritis Res. 2002. 4 Suppl 3: S169-176.

Castelli WP. Epidemiology of triglycerides: A view from framingham. Am J Cardiol. 1992. 70: 3H-9H.

Coppack SW. Pro-inflammatory cytokines and adipose tissue. Proc Nutr Soc. 2001. 60: 349-356.

Costa Rosa LF. Exercise as a time-conditioning effector in chronic disease: A complementary treatment strategy. Evid Based Complement Alternat Med. 2004. 1: 63-70.

Dziarski R, Jin YP, Gupta D. Differential activation of extracellular signal-regulated kinase (erk) 1, erk2, p38, and c-jun nh2terminal kinase mitogen-activated protein kinases by bacterial peptidoglycan. J Infect Dis. 1996. 174: 777-785. 
Firestein GS, Zvaifler NJ. How important are t cells in chronic rheumatoid synovitis?: Ii. T cell-independent mechanisms from beginning to end. Arthritis Rheum. 2002. 46: 298-308.

Gil A, Maria Aguilera C, Gil-Campos M, Canete R. Altered signalling and gene expression associated with the immune system and the inflammatory response in obesity. Br J Nutr. 2007. 98 Suppl 1: S121-126.

Gotto AM, Jr. Triglyceride: The forgotten risk factor. Circulation. 1998. 97: 1027-1028.

Juge-Aubry CE, Somm E, Pernin A, Alizadeh N, Giusti V, Dayer JM, Meier CA. Adipose tissue is a regulated source of interleukin10. Cytokine. 2005. 29: 270-274.

Kanayama A, Seth RB, Sun L, Ea CK, Hong M, Shaito A, Chiu YH, Deng L, Chen ZJ. Tab2 and tab3 activate the nf-kappab pathway through binding to polyubiquitin chains. Mol Cell. 2004. 15: 535-548.

Kastelein JJ, van der Steeg WA, Holme I, Gaffney M, Cater NB, Barter P, Deedwania P, Olsson AG, Boekholdt SM, Demicco DA, Szarek M, LaRosa JC, Pedersen TR, Grundy SM, Group TNTS, Group IS. Lipids, apolipoproteins, and their ratios in relation to cardiovascular events with statin treatment. Circulation. 2008. 117: 3002-3009.

Kyriakis JM, Banerjee P, Nikolakaki E, Dai T, Rubie EA, Ahmad MF, Avruch J, Woodgett JR. The stress-activated protein kinase subfamily of c-jun kinases. Nature. 1994. 369: 156-160.

Lee JC, Laydon JT, McDonnell PC, Gallagher TF, Kumar S, Green D, McNulty D, Blumenthal MJ, Heys JR, Landvatter SW, Strickler JE, McLaughlin MM, Siemens IR, Fisher SM, Livi GP, White JR, Adams JL, Young PR. A protein kinase involved in the regulation of inflammatory cytokine biosynthesis. Nature. 1994. 372: $739-746$

Libby P. Inflammation in atherosclerosis. Arterioscler Thromb Vasc Biol. 2012. 32: 2045-2051.

Libby P, Ridker PM, Maseri A. Inflammation and atherosclerosis. Circulation. 2002. 105: 1135-1143.

Lira FS, Rosa JC, Zanchi NE, Yamashita AS, Lopes RD, Lopes AC, Batista ML, Jr., Seelaender M. Regulation of inflammation in the adipose tissue in cancer cachexia: Effect of exercise. Cell
Biochem Funct. 2009. 27: 71-75.

Malloy MJ, Kane JP. A risk factor for atherosclerosis: Triglyceriderich lipoproteins. Adv Intern Med. 2001. 47: 111-136.

Mund RC, Pizato N, Bonatto S, Nunes EA, Vicenzi T, Tanhoffer R, de Oliveira HH, Curi R, Calder PC, Fernandes LC. Decreased tumor growth in walker 256 tumor-bearing rats chronically supplemented with fish oil involves cox-2 and pge2 reduction associated with apoptosis and increased peroxidation. Prostaglandins Leukot Essent Fatty Acids. 2007. 76: 113-120.

Paiva AA, Raposo HF, Wanschel AC, Nardelli TR, Oliveira HC. Apolipoprotein ciii overexpression-induced hypertriglyceridemia increases nonalcoholic fatty liver disease in association with inflammation and cell death. Oxid Med Cell Longev. 2017. 2017: 1838679.

Robertson AK, Hansson GK. T cells in atherogenesis: For better or for worse? Arterioscler Thromb Vasc Biol. 2006. 26: 2421 -2432 .

Ross R. Atherosclerosis--an inflammatory disease. N Engl J Med. 1999. 340: 115-126.

Sofer O, Fainaru M, Schafer Z, Goldman R. Regulation of lipoprotein lipase secretion in murine macrophages during foam cell formation in vitro. Effect of triglyceride-rich lipoproteins. Arterioscler Thromb. 1992. 12: 1458-1466.

Son SJ, Rhee KJ, Lim J, Kim TU, Kim TJ, Kim YS. Triglycerideinduced macrophage cell death is triggered by caspase-1. Biol Pharm Bull. 2013. 36: 108-113.

Weinstein SL, Sanghera JS, Lemke K, DeFranco AL, Pelech SL. Bacterial lipopolysaccharide induces tyrosine phosphorylation and activation of mitogen-activated protein kinases in macrophages. J Biol Chem. 1992. 267: 14955-14962.

https://doi.org/10.15616/BSL.2018.24.3.213

Cite this article as: Lim JW, Yang EJ, Chang JH Upregulation of TNF- $\alpha$ by Triglycerides is Mediated by MEK1 Activation in Jurkat T Cells. Biomedical Science Letters. 2018. 24: 213-220. 